\title{
Academic achievement: Intelligence, regulatory, and cognitive predictors
}

\author{
Varvara I. Morosanova, Tatiana.G. Fomina, Irina N. Bondarenko* \\ Psychological Institute of the Russian Academy of Education, Moscow, Russia \\ *Corresponding author. E-mail: pondi@inbox.ru
}

\begin{abstract}
Using the results of two empirical studies (with different samples and academic subjects), our research was aimed at discovering the significant role of conscious self-regulation, intelligence, and cognitive features in predicting optimal academic achievement. The sample consisted of 406 students (aged 14-16) in the 8th to 11th grades of the Russian formal education system. Conscious self-regulation together with intelligence and cognitive abilities was determined to be a significant predictor of academic success. The Study 1 results revealed that the general level of self-regulation of learning activity and certain regulatory features were significant predictors of different types of mathematical achievements: academic grades, scores on exams, mathematical fluency, as well as solving logical mathematical problems and equations. The present study is the first to show the mediating role of self-regulation in relation to intelligence, cognitive features, and academic success. Study 2 found evidence that conscious self-regulation and intelligence can predict academic achievement in the humanities, mathematics, and natural sciences.. At the same time, this determination has its peculiarities in particular variables of intelligence and certain self-regulation processes depending on the substantive characteristics of the academic subjects. Regression models of academic success in the humanities identified verbal intelligence associated with vocabulary as highly significant and a definitive requirement for success in these subjects. Study 1 and Study 2 showed that the only significant predictors of success in algebra and geometry were quantitativerelations intelligence and spatial intelligence. The implications of these findings for investigating predictors of academic achievement are discussed.
\end{abstract}

Keywords: conscious self-regulation, intelligence, cognitive features, gifted students, academic achievement

\section{Introduction}

The psychological factors in academic success are a hot point in modern psychology. For a long time research efforts have been focused on cognitive features and intelligence as predictors of academic success. Yet empirical results differ in as- 
sessing the contribution of intelligence to academic achievement. According to meta-analysis results, some researchers report that the interrelationship between academic success and psychometric intelligence is determined within 0.29-0.40 (Gordeeva, 2013; Kornilov, Grigorenko, \& Smirnov, 2009), while other studies reveal this interrelationship to be 0.40-0.63 (Bartels, Rietveld, Van Baal, \& Boomsma, 2002; Brody, 2004; Krapohl et al., 2014; Spinath, Spinath, Harlaar, \& Plomin, 2006; Sternberg, Grigorenko, \& Bundy, 2001). However, researchers point out that intelligence is a key predictor of students' academic success; intelligence explains $25 \%$ of the variance of indicators of academic success (Gottfredson, 2004; Sternberg et al., 2001).

Many research efforts are focused on the noncognitive factors influencing students' academic success. Scientists discovered among them a number of personal predictors: motivation, self-esteem, self-efficacy, personal potential, and the "Big Five" factors (Gordeeva, Leontiev, \& Osin, 2011; Gordeeva \& Osin, 2012; Kochergina, Nye, \& Orel, 2013; Kornilova, Kornilov, \& Chumakova, 2009; Kornilova \& Novikova, 2013; Krapohl et al., 2014; Smirnov, Kornilova, Kornilov, \& Malakhova, 2007; Spinath et al., 2006; Steinmayr \& Spinath, 2009).

In addition, researchers have suggested self-regulation (SR) as an essential factor in students' academic success (Boekaerts, Pintrich, \& Zeidner, 2005; Diseth \& Kobbeltvedt, 2010; Elliot, McGregor, \& Gable, 1999; Pintrich \& De Groot, 1990; Zimmerman \& Schunk, 1989). However, there is no common understanding of what a phenomenon of SR is and which features are to be considered SR components. Most researchers focus on goal setting - the ability to set learning goals (Schunk, 1990; Zimmerman, Bandura, \& Martinez-Pons, 1992). Other scientists analyze volitional (Corno, 2001), cognitive (Winne, 1995), and sociocultural (McCaslin and Hickey, 2001) aspects of SR.

In Russia the problem of the interrelationship between SR and academic achievement is considered in the context of both personality psychology (Ivannikov, 2006; Leontiev, 2011) and cognitive psychology (Kornilova, 2008; Sergienko, 2008). It is difficult to interpret conscious SR as a purely personal or cognitive factor. Nowadays SR is often viewed as a meta-cognitive process that organizes learning by coordinating primary cognitive processes (Karpov, 2011). Overall, it is a paradoxical situation: the impact of SR on learning activity is not disputed, but the contribution of regulatory processes is difficult to assess because of different methodological positions resulting in different research organization.

The main goal of the present article is to introduce the standpoint of the scientific school of SR psychology developed by the Psychological Institute of the Russian Academy of Education. Equally important to us is the task of evaluating and comparing the contribution of regulatory, cognitive, and intellectual factors to academic success based on the results of our recent empirical studies.

\section{The basic concept: Self-regulation}

We define self-regulation as a process of conscious self-organization of psychic activity that assures goal setting and achievement of results corresponding to these goals. SR is realized through a wholesome, multilevel system that has a particular 
structure of interrelated components. A conceptual model of the conscious SR system includes the main functional components: activity goal (as it is understood and accepted by the subject); subjective model of the activity conditions significant for goal achievement; program of the activity; system of criteria for goal achievement; evaluation and correction of the activity results (Konopkin, 2011).

We distinguish between stylistic features of the manifestation of regulatory processes for implementing the main components of the psychic SR system (operational level), regulatory-personal features (temperamental and characterological level), and the general (integrative) level of SR, which characterizes the development of a person's subjective activity. Stylistic features are a prerequisite for the formation of individual styles in specific professional and learning activities - to the extent to which the individual is aware of them. Thus, we consider SR stylistic features as an individual's psychological resource (Morosanova, 2010).

The results of theoretical and empirical studies allow us to suggest that conscious SR may act as a metacognitive factor that is involved in learning activity and mobilizes cognitive and personal resources for the achievement of learning goals (Morosanova, 2014). Any learning activity is a specific kind of voluntary activity, and its effectiveness is determined by stylistic features of SR. Studies show that students' academic success depends on the degree of SR development and the SR stylistic features (Konopkin \& Prygin, 1984; Kruglova, 2000; Morosanova, 2013a); Morosanova, Fomina, \& Kovas, 2014). It had been shown that students with higher motivation and SR achieve significantly better results, have a positive attitude to learning, and successfully adapt to the changing conditions of the learning process (Morosanova \& Filippova, 2009; Morosanova, Filippova, \& Fomina, 2014).

Our extended studies enable us to state that conscious SR is a meta-resource: it has universal and special competence to put forward and to manage the process of goal achievement. Cognitive features, temperament, character, and self-consciousness are the differential foundation of these competencies. Universal and special competencies mobilize, integrate, and mediate the effects of these personality features on human behavior (Morosanova, 2014). Students' ability to organize their own learning activity so as to achieve success depends on the level of conscious SR development and the specificity of the profile of SR stylistic features (Konopkin \& Prygin, 1984; Kruglova, 2000; Morosanova, 2013b; Morosanova, Fomina, \& Kovas, 2014).

Thus, we and our foreign colleagues, through sharing similar theoretical and methodological positions (Bouffard et al., 1995; Zimmerman et al., 1992; Zimmerman \& Schunk, 1989), established the regulatory predictors of academic success.

Therefore, the main questions we put for our studies are as follows. What is the relationship between high school students' cognitive abilities, regulatory characteristics, and mathematical achievements? Do regulatory characteristics contribute to mathematical achievement along with cognitive abilities? Are there any significant peculiarities of the joint effect of SR and intelligence on the achievement of various school subjects? If SR is a meta-resource, then how does it manifest its mediating role between cognitive and intellectual characteristics and their impact on students' academic success? 


\section{Study 1. Conscious self-regulation: contribution to academic achievement and the mediator role in relations among cognitive characteristics, mathematical abilities, and mathematical success}

Researchers present much evidence that mathematical achievement is independently associated with cognitive characteristics: general intelligence, number sense, spatial memory, and reaction time (Geary, 2011; Rodic etal., 2015; Rohde \& Thompson, 2007; Ross, Budakova, Malykh, \& Vorobyev, 2012; Tikhomirova \& Kovas, 2012). However, these cognitive characteristics explain both a modest and a moderate amount of variance of mathematical ability and achievement, a finding that suggests that other, perhaps noncognitive factors are also important. Thus, motivational and personality factors (self-efficacy, self-perceived ability) predict mathematical achievement and explain its additional unique variance (Cleary \& Chen, 2009; Dirik, Bogdanova, \& Kovas, 2012; Gordeeva \& Osin, 2012; Greven, Harlaar, Kovas, Chamorro-Premuzic, \& Plomin, 2009; Hackett \& Betz, 1989; Luo, Kovas, Haworth, \& Plomin, 2011; Spinath et al., 2006; Steinmayr \& Spinath, 2009).

The present research investigates in detail the relationships among different aspects of self-regulation, mathematically relevant cognitive characteristics, and mathematical achievements. In addition, the study analyzes the role of SR as a mediator between cognitive characteristics, mathematical abilities, and mathematical achievements.

\section{Methods}

\section{Participants}

The sample included 318 (158 males) $14-16$ year old students (mean age $=15.1$ ) educated in state secondary schools in Russia. All participants were in the 9th grade (out of 11) of the Russian formal educational system. Everyone participated on a voluntary basis with written agreement of the parents.

\section{Procedure}

Regulatory features, cognitive characteristics, and mathematical outcomes were assessed. Participants completed a battery of tests in groups in their schools' computer classes during the first half of the school day. All tests and questionnaires were completed in the same order during one session in the presence of a researcher.

\section{Measures}

Regulatory features. The Self-Regulation Profile of Learning Activity Questionnaire (SRPLAQ; Morosanova, 2010), a version of the Self-Regulation Profile Questionnaire, was used to assess regulatory features.

SRPLAQ includes 67 statements that describe typical situations concerning the achievement of learning goals. These statements are grouped into the following nine scales, each composed of nine items: planning (as setting and achieving goals), modeling (of significant, subjective internal and external conditions for goal achievement), programming (of actions), results evaluation, flexibility, independence, reliability, responsibility, social desirability (Morosanova, Vanin, \& Tsyganov, 2011). Each statement is rated on a scale of 4 (yes, probably yes, prob- 
ably no, no). High scores (maximum 9) denote high self-regulation. An integrative scale - the general level of conscious SR - is estimated by adding the scores together (maximum 58). Cronbach's alpha for each scale ranged from 0.58 to 0.76 . The subscales were significantly correlated with each other $(r=0.22-0.66, p<.01)$. The general level of the SRPLAQ was positively correlated with the students' exam performance $(r=0.434, p<.01)$. Cognitive characteristics. The cognitive test battery assessed cognitive characteristics that were previously linked to mathematical ability, including number sense, spatial memory, spatial ability, reaction time, and general intelligence. The following seven tests were included. The tests of number sense were:

The Dot-Number Task assesses the comparison of symbolically and nonsymbolically indicated numerosities. The total number of correct responses is registered.

The Number Line Test assesses the estimation of numerical magnitudes; it was programmed and implemented online based on a description in Opfer and Siegler (2007). The scores are calculated as the mean of the deviations from the correct position of the numbers on the line.

The Dot Task assesses the ability to differentiate numerosities. The task is a variation of the dot task developed by Ginsburg and Baroody (1990) and is programmed online based on the description found in Halberda, Mazzocco, and Feigenson (2008). The total number of correct responses is registered.

The tests for other cognitive characteristics were:

The Reaction Time Task assesses response reaction time; it was programmed following the procedure described in Deary, Der, and Ford (2001).

The Corsi Block Test, adapted for online use from Pagulayan, Busch, Medina, Bartok, and Krikorian (2006), assesses spatial working memory. The program records accuracy and reaction time for each trial.

The Mental Rotation Task, based on the task created by Shepard and Metzler (1971), is used to measure spatial ability. The test consists of 180 trials, and participants are asked to answer as many questions as possible in 3 minutes.

General Intelligence was assessed using Raven's progressive matrices, adapted from Raven, Court, \& Raven (1996). It is a measure of general fluid intelligence, or nonverbal IQ.

Mathematical outcomes. The tests for mathematical achievement and ability were:

The Problem Verification Task (PVT) is an online adaptation of a test, described in Murphy and Mazzocco (2008), to assess mathematical fluency. Stimulus material is presented in the form of an already solved mathematical task. The participant decides whether a given answer is correct or not. This test evaluates the ability to perform basic mathematical operations quickly and 
accurately and therefore can be considered as an indicator of success in mathematics. We used the result of the PVT test also as an indicator of mathematical ability, which in turn determines mathematical outcomes.

Understanding Numbers assesses mathematical achievement according to the standards of the UK National Curriculum. The test comprises 18 items arranged in increasing level of difficulty and organized in three levels of six items each. We used the results of this test as an indicator of both success in mathematics and mathematical ability, which in turn determines the mathematical outcomes.

The Year Math Grade is the grade received for algebra for the whole year; a grade was obtained for all students using school registers. Russian schools assess student achievement on a 5-point scale throughout their education.

The State Exam Grade for mathematics was obtained from school records for each student. The result of this examination is a score on a $0-38$ scale.

\section{Results}

\section{Correlations}

We evaluated mathematical achievement from two points of view. We used some mathematical abilities (mathematical fluency, understanding and successfully solving logical tasks) as well as the Year Math Grade and the State Exam Grade. Correlation analysis of mathematical ability and mathematical outcomes showed a significant, moderate relationship $(r=0.29-0.35 p<.01)$. This result supported our hypothesis that high mathematical ability is not a single-valued predictor of high mathematical achievement. Significant correlations with measures of mathematical performance were found both for cognitive and for regulatory characteristics (Morosanova, Shcheblanova, Bondarenko, \& Sidikov, 2013; Morosanova, Morosanova, Fomina, \& Kovas, 2014). An analysis of these relationships was provided in our previous publications (Morosanova, Fomina, \& Kovas, 2014; Morosanova, Filippova, \& Fomina, 2014). Indeed, most of the significant correlations revealed between mathematical outcomes and cognitive characteristics were as expected. But we also identified regulatory characteristics associated with mathematical achievement. Thus, modeling correlated with the PVT (mathematical fluency) $(r=0.15$, $p<.05)$, Understanding Numbers $(r=0.21, p<.01)$, the Year Math Grade $(r=0.25$, $p<.01)$, and the State Exam Grade $(r=0.17, p<.01)$. Results evaluation correlated with the Year Math Grade $(r=0.22, p<.01)$. Self-dependence correlated with the Year Math Grade $(r=0.14, p<.05)$. Reliability correlated with Understanding Numbers $(r=0.14, p<.05)$. Responsibility correlated with the Year Math Grade $(r=0.12$, $p<.05)$. The general level of SR correlated with Understanding Numbers $(r=0.14$, $p<.05)$ and the Year Math Grade $(r=0.24, p<.01)$. Five regulatory features, including the general level of SR, correlated with the Year Math Grade.

\section{Regression analyses}

Regression analysis showed that both cognitive and regulatory features are significant predictors of different types of mathematical success. We carried out four regression analyses with mathematics outcomes as the dependent variables (math- 
ematical fluency; Understanding Numbers; the Year Math Grade; the State Exam Grade) and with seven cognitive measures and eight subscales of SR as the independent variables.

We also re-ran these analyses, including the general level of SR instead of eight subscales. The results showed that the general level of SR was a significant predictor of mathematical fluency, Understanding Numbers, and the Year Math Grade (Morosanova, Fomina, \& Kovas, 2014).

The study results allowed us to analyze the peculiar character of relationships between certain regulatory predictors and different aspects of mathematical achievement. Thus, flexibility was a significant predictor of mathematical fluency $(\beta=0.14, p<.05)$; reliability $(\beta=0.16, p<.05)$ and modelling $(\beta=0.14, p<.05)$ predicted Understanding Numbers; responsibility $(\beta=-.22, p<.05)$ and goal planning $(\beta=0.21, p<.05)$ were predictors of the State Exam Grade.

The relationships between cognitive measures (abilities) and mathematical achievement also differ in the details. General Intelligence $(\beta=0.21, p<.001)$, visuospatial memory $(\beta=0.19, p<.01)$, number sense $(\beta=0.14, p<.05)$, and the Mental Rotation Task $(\beta=0.16, p<.01)$ proved to be significant predictors of mathematical fluency (PVT). Number sense $(\beta=0.25, p<0.001)$, General Intelligence $(\beta=0.15$, $p<.05)$, and the Mental Rotation Task $(\beta=0.15, p<.05)$ were significant predictors of Understanding Numbers. Visuospatial memory $(\beta=0.16, p<.05)$ and number sense $(\beta=0.15, p<.05)$ predicted the State Exam Grade.

Regression analyses showed that independent variables explained from $17 \%$ to $29 \%$ of the mathematical achievement variance.

\section{Mediator analysis}

Mediator hypothesis checking was carried out by analyzing several series of multiple regression analyses and using the Sobel test. In the final models, of all our SR independent variables, only the regulatory process of modeling was revealed to be a significant predictor of the Year Math Grade. Its mediator effect was verified in an analysis with nonverbal intelligence and the Number Line Test results as independent variables; they proved to be significant predictors of academic success (the Year Math Grade was taken as a dependent variable). In addition, we found that modeling played a mediating role between mathematical abilities and academic success. We observed a mediating effect for the independent variables mathematical fluency and Understanding Numbers.

Table 1 summarizes the statistical parameters of the mediator analyses. The Sobel test confirmed the partial mediator effect of modeling. It should be noted that the mediator effect was observed for the dependent variable Year Math Grade only.

Modeling allows an assessment of students' ability to discover and effectively use learning conditions that are necessary for the achievement of learning goals. Apart from being an important feature for learning in general, it is possible that modeling is particularly important specifically for mathematical learning. When solving mathematical problems, it is necessary to analyze the relevant learning conditions. 
Table 1. The statistical parameters of mediator models and Sobel test results

\begin{tabular}{|c|c|c|c|c|c|c|c|c|}
\hline \multirow{2}{*}{ Predictors } & \multirow{2}{*}{ Mediator } & \multirow{2}{*}{$\begin{array}{l}\text { Dependent } \\
\text { variable }\end{array}$} & \multicolumn{4}{|c|}{ Regression analysis } & \multicolumn{2}{|c|}{ Sobel test } \\
\hline & & & $\mathbf{a}$ & $\mathbf{b}$ & c & $c^{\prime}$ & $\mathrm{Z}$ & $\mathbf{P}$ \\
\hline $\begin{array}{l}\text { General } \\
\text { Intelligence }\end{array}$ & Modeling & $\begin{array}{l}\text { Year Math } \\
\text { Grade }\end{array}$ & $0.07^{\star}$ & $0.08^{* * *}$ & $0.04^{* * *}$ & $0.03^{* * *}$ & 1.97 & 0.04 \\
\hline $\begin{array}{l}\text { Number } \\
\text { Line Test }\end{array}$ & Modeling & $\begin{array}{l}\text { Year Math } \\
\text { Grade }\end{array}$ & $-0.02^{\star}$ & $0.08^{* * *}$ & $-0.008^{* * *}$ & $-0.007^{\star * *}$ & 2.10 & 0.03 \\
\hline $\begin{array}{l}\text { Mathematical } \\
\text { fluency }\end{array}$ & Modeling & $\begin{array}{l}\text { Year Math } \\
\text { Grade }\end{array}$ & 0.06 & $0.08^{* * *}$ & $0.05^{\star \star \star}$ & $0.05^{\star * *}$ & 2.03 & 0.04 \\
\hline $\begin{array}{l}\text { Understanding } \\
\text { Numbers }\end{array}$ & Modeling & $\begin{array}{l}\text { Year Math } \\
\text { Grade }\end{array}$ & 0.13 & $0.08^{* * *}$ & $0.072^{\star * \star}$ & $0.06^{* * *}$ & 2.34 & 0.02 \\
\hline
\end{tabular}

Note: Nonstandardized regression coefficients were used. ${ }^{\star} p=.05 .{ }^{* *} p=.001$.

The results showed that modeling mediated the relationship between academic success and General Intelligence. This regulatory process contributed to optimal use of the intellectual resources of a student's learning activity.

The mediator effect of SR had also been revealed in regard to number sense while accomplishing the Number Line Test. The process of analyzing task conditions seems to us similar to mental actions that a student performs when comparing a number and the scale length of a line. So the role of modeling here seems logical.

The results suggest that cognitive and regulatory features are independently associated with mathematical outcomes, and the relationships differ depending on the specific aspect of mathematical achievement.

Cognitive features predict mathematical fluency and success in solving logic tasks. Meanwhile, the SR features predict academic achievement in mathematics. Therefore, we have established that both cognitive and regulatory variables are significant and independent predictors of mathematical success.

\section{Study 2. Intelligence and self-regulation as predictors of gifted adolescents' academic success}

Study 2 was aimed at identifying intellectual and regulatory predictors of academic achievement in the humanities, mathematics, and natural sciences in the sample of gifted children. Despite the seeming obviousness of the positive role of intellectual and regulatory factors in academic success, data from different empirical studies were contradictory. It was found that only children with high intelligence could be successful at learning; however, among unsuccessful students there were children with both high and low intelligence (Biryukov \& Khodakova, 1999; Druzhinin, 2001; Golubeva, Izyumova, \& Kabardov, 1991). Other researchers found no correlations between Russian students' academic success and their analytical, practical, and creative intelligence (Bordovskaya \& Rean, 2000; Ishkov, 2004; Kornilov, 2012). In contrast, meta-analyses by Poropat (2009) and by Richardson, Abraham, and Bond (2012) have shown a relationship between intelligence and high school students' academic success at $r=0.20, N=8000$. 
Therefore, we've set mainly the following research questions: Does conscious SR predict gifted students' academic success? What part of academic success variance does it explain?

All the students in the Study 2 sample had a high level of intelligence, and so its contribution to the total variance was reduced. Teachers and psychologists working with gifted children agree that a low level of SR is one of the main hindrances to gifted children's realizing their extraordinary intellectual and creative potential in learning activity. Researchers have identified defects of SR such as impulsivity, disorganization, and lack of attention (Reis \& McCoach, 2002). We revealed that conscious SR encourages certain traits of temperament and character, and alters functional conditions, thereby hindering learning and the achievement of professional goals (Morosanova, 2014). However, to date, the role of conscious SR and its specific relations with intelligence in maintaining high academic achievement for gifted students is not clearly understood.

We formulated the following hypotheses:

Hypothesis 1. General levels of verbal, mathematical, and nonverbal intelligence and the general level of conscious SR significantly predict the academic achievement of gifted adolescents.

Hypothesis 2. The academic achievement of gifted students in the humanities, mathematics, and natural sciences is determined by particular variables of intelligence and certain regulatory processes.

\section{Methods}

The study was based on questionnaire data collected during several school days. Individual forms were used to answer the questions and to perform test tasks.

\section{Participants}

A total of 87 students of Moscow gymnasium no. 1569, Constellation, for gifted children participated in the study. The sample included 40 boys and 47 girls aged 14-16 in the 8th, 9th and 12th grades of the Russian formal education system. Everyone participated on a voluntary basis with written agreement from their parents.

The high academic achievement of the students was manifested in learning outcomes, the results of academic competitions, intellectual marathons, scientific and practical conferences. We have previously demonstrated that these students have significantly higher intellectual development test results than students of ordinary schools (Morosanova et al., 2013).

\section{Measures}

The Self-Regulation Profile of Learning Activity Questionnaire (SRPLAQ; Morosanova, 2011) was used to assess regulatory features.

The Munich Test of Cognitive Abilities for Gifted Students (Kognitiver Fahigkeit Test, KFT) is a test for measuring intelligence level. We used the Russian ad- 
aptation of the KFT (Averina, Shcheblanova \& Perlet, 1991; Shcheblanova, 2004). The test is used for students who are an average of two years ahead of their peers in the development of general intelligence and specific intellectual abilities. It contains three scales - verbal $(\mathrm{V})$, mathematical $(\mathrm{Q})$, and nonverbal $(\mathrm{N})$ intelligence. Each scale consists of two subscales with 25 to 30 tasks. The verbal scale includes a vocabulary test (V1) and an incomplete-sentence test (V2). The mathematical scale includes a quantitative-relations test (Q2) and a generation-of-equation test (Q4); the nonverbal (spatial) test includes a geometric figure-sorting test (N1) and a figure analogues test (N2).

We used the Year Grades from the 2011-2012 academic year to assess student academic achievement.

\section{Results}

\section{Correlation analysis}

Correlation analysis revealed significant positive correlations between intelligence and academic outcomes in all nine academic subjects. Significant correlations were found between variables of verbal and mathematical intelligence and academic outcomes in all the disciplines $(r<=0.21, p<.05$ and $r<=0.37, p<.01)$.

The results of correlation analysis showed that variables of conscious SR such as planning, modeling, programming, results evaluation, and general level of SR were positively associated with academic achievement in the humanities and mathematics $(r=0.22-0.30, p<.05)$. The Results evaluation correlated with academic outcomes in six subjects (Russian language, literature, history, algebra, geometry, computer science). Obviously, having an intellectual gift is not enough to be successful. It is important to be self-organized to meet the one's own aspirations and teachers' demands. To achieve high academic outcomes gifted students need reflection, selfcriticism, and perfectionism as well as susceptibility to feedback from teachers and peers (Morosanova et al., 2013).

\section{Regression analysis}

In order to test Hypotheses 1 and 2 we used linear regression analysis for the Year Grades in the humanities, mathematics, and natural sciences (the dependent variables). As independent variables we used particular characteristics of intelligence and four regulatory parameters plus the general level of SR as a sum of SR processes (GL SR (processes)). We have included in linear regression equations only those variables that showed significant correlations with academic success in the relevant subjects.

In the final regression models of gifted students' achievement, we assessed the contribution of appropriate variables of intelligence and self-regulation. In the first step, general levels of intelligence and self-regulation (the left column of Table 2) were included in the model. In the second step, we included specific variables of verbal, nonverbal, and mathematical intelligence and four processes of self-regulation (the right column of Table 2).

As Table 2 shows, the general level of self-regulation is a significant predictor of academic success in all the subjects along with intelligence. 
Table 2. Regression analysis, variables of intelligence, self-regulation, and academic outcomes in the humanities, mathematics, and natural sciences

\begin{tabular}{|c|c|c|c|c|}
\hline \multirow{2}{*}{ 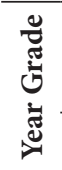 } & \multicolumn{2}{|c|}{$\begin{array}{l}\text { Regression models with general } \\
\text { level of independent variables }\end{array}$} & \multicolumn{2}{|c|}{$\begin{array}{l}\text { Regression models with partial variables of } \\
\text { intelligence and self-regulation processes }\end{array}$} \\
\hline & Predictors & $\beta$ & Predictors & $\beta$ \\
\hline \multirow{5}{*}{ 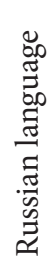 } & Constant & $1.09^{* *}$ & Constant & $1.09^{* *}$ \\
\hline & & & V1 (vocabulary test) & $0.36^{* * *}$ \\
\hline & (verbal) & $0.53^{x+x}$ & V2 (incomplete sentence) test) & $0.26^{* *}$ \\
\hline & GL SR(processes) & $0.28^{* *}$ & Programming & $0.30^{* * *}$ \\
\hline & $R^{2}=0.38$ & $F=23,77^{\star * *}$ & $R^{2}=0.43$ & $9^{* * *}$ \\
\hline \multirow{4}{*}{ 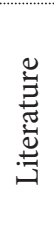 } & Constant & $2.89^{* * *}$ & Constant & $2.63^{\star * *}$ \\
\hline & V (verbal) intelligence) & $0.32^{\star * *}$ & V1 (vocabulary test) & $0.32^{\star *}$ \\
\hline & GL SR(processes) & $0.27^{\star * *}$ & Planning & $0.55^{\star * *}$ \\
\hline & $R^{2}=0.16$ & $F=8.48^{* * \star}$ & $R^{2}=0.44$ & $88^{* * *}$ \\
\hline \multirow{5}{*}{ 莺 } & Constant & $2.50^{* \star \star}$ & Constant & $2.28^{\star * \star}$ \\
\hline & $\mathrm{V}$ (verbal) & $0.6^{* * *}$ & V1 (vocabulary test) & $0.50^{\star * *}$ \\
\hline & & & Programming & $0.21^{* *}$ \\
\hline & GL SR(processes) & $0.18^{\wedge}$ & Modeling & $0.19^{*}$ \\
\hline & $R^{2}=0.32$ & $0.25^{* * *}$ & $R^{2}=0.44$ & $04^{\star * *}$ \\
\hline \multirow{5}{*}{$\begin{array}{l}\pi \\
\frac{\pi}{2} \\
\frac{0}{2} \\
\frac{0}{4}\end{array}$} & Constant & $1.96^{* * *}$ & Constant & $2.59^{* \star *}$ \\
\hline & $\mathrm{Q}$ (math) & $0.29^{\star * *}$ & Q2 (quantitative relations) & $0.32^{* * *}$ \\
\hline & $\mathrm{N}$ (nonverbal) & $0.24^{\star}$ & N2 (figure analogues test) & $0.25^{\star}$ \\
\hline & GL SR(processes) & $0.22^{*}$ & Results evaluation & $0.26^{\star \star}$ \\
\hline & $R^{2}=0.23$ & $2.8^{* * *}$ & $R^{2}=0.23$ & $62^{* * *}$ \\
\hline \multirow{6}{*}{ 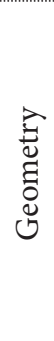 } & Constant & $1.36^{* * *}$ & & \\
\hline & $\mathrm{V}$ (verbal) & $0.32^{\star * *}$ & V1 (vocabulary test) & $0.27^{\star * *}$ \\
\hline & Q (math) intelligence & $0.29^{\star * *}$ & Q2 (quantitative relations) & $0.33^{\star * *}$ \\
\hline & $\mathrm{N}$ (nonverbal) & $0.25^{\star * \star}$ & N2 (figure analogues test) & $0.38^{\star * *}$ \\
\hline & GL SR(processes) & $0.21^{*}$ & Modeling & $0.19^{*}$ \\
\hline & $R^{2}=0.40$ & $F=17.48^{\star * *}$ & $R^{2}=0.53$ & $39^{\star * *}$ \\
\hline \multirow{4}{*}{ 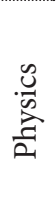 } & Constant & $2.92^{* \star \star}$ & & \\
\hline & Q (math) intelligence & $0.43^{* * *}$ & & \\
\hline & GL SR(processes) & $0.19(0.06)$ & & \\
\hline & $R^{2}=0.22$ & $F=11.7^{\star * *}$ & & \\
\hline
\end{tabular}


Analyzing the study results, we'd like to highlight a number of facts. Academic achievement in the humanities is predicted by verbal intelligence and self-regulation (they explained 38\% of the variance in Russian language, 16\% in Literature, $32 \%$ in History). Although the specific character of different subjects requires diverse intellectual resources, verbal intellect as determined by the students' vocabulary (idiolect) turned out to be a significant general predictor of achievement for all three subject clusters.

As for the regulatory processes, programming was a significant predictor for Russian language $(\beta=0.30, p<.000)$, planning for literature $(\beta=0.55, p<.000)$, and both programming $(\beta=0.21, p<.001)$ and modeling $(\beta=.19, p<.05)$ were significant predictors for history.

Mathematical achievement is also determined by particular parameters of intelligence and self-regulation (our independent variables explained 23\% of the variance in algebra and $40 \%$ in geometry). Thus, only quantitative-relations intelligence (Q2) and figure analogues intelligence (N2) were significant predictors of mathematical success. As for our SR variables, results evaluation proved to be a significant predictor for achievement in algebra $(\beta=0.26, p<.001)$ and modeling was significant for geometry $(\beta=0.19, p<.05)$.

Concerning natural subjects, regression analysis for physics showed that independent variables explained $22 \%$ of the variance. The regression model turned out to be significant only for general levels of intelligence and SR because particular intellectual and regulatory parameters didn't show relevant significance. Hence, we can assume that academic achievement in natural sciences is predicted mostly by the general development of self-regulation and intelligence, not by their particular aspects. However, this assumption needs further verification.

\section{Discussion}

The empirical results presented here support our hypotheses that conscious SR is a significant predictor of academic achievement along with cognitive characteristics and intelligence. Our study is the first one to prove empirically the mediator role of SR regarding cognitive and intellectual determinants of academic achievement. The model we've managed to create demonstrates that conscious $\mathrm{SR}$, in addition to its direct beneficial effect on mathematical success, mediates those impacts contributed by general intelligence, mathematical fluency, and understanding numbers.

The mechanism of this influence is character-specific depending on the situation. When the situation requires on-the-fly efficiency in task solving (mathematical fluency), cognitive features (spatial memory, number sense) take on special significance. But if the situation presupposes full-scale and conscious processes for organizing one's cognitive activity, then the subject's conscious SR starts playing to advantage.

One more fact is worth a special discussion. In the mediator model of academic achievement conscious SR is presented by the modeling parameter. It characterizes individual development of a student's conception of the internal and external conditions significant for the achievement of learning goals and the 
range of their comprehension, adequacy, and detailed elaboration. High ranges of modeling development promote swift inclusion into the learning situation, rapid adaptation to changes, accommodation of a challenging situation, and so forth.

We obtained important new data concerning the cognitive predictors of mathematical achievement. In our Study 1 spatial memory turned out to be the only significant cognitive predictor of the Year Math Exam Grade. The study also revealed a significant role of number sense as predictor of mathematical success both in solving mathematical tasks and providing State Exam Grade for Mathematics. This fact corresponds to foreign data (Siegler \& Opfer, 2003) but is not always fixed on the Russian-speaking samples (Tikhomirova \& Kovas, 2013).

In our Study 2 we assessed the contribution of intelligence and SR to academic achievement with regard to different subjects' specific characters. The results revealed intelligence and SR to be significant predictors of the gifted students' Year Grades - whether in the humanities, mathematics, or natural sciences.

Our results complement those studies that have shown the significant contribution of intelligence to high academic results. For example, the results of a Moscow longitudinal study showed that outcomes for gifted students were related to their level of intelligence, and the intensity of this relationship depended on the subject: it was higher in mathematics and lower in literature and Russian and foreign languages (Shcheblanova, 1999, 2013; Shumakova, 2006). Our results showed a different tendency: the dependence of achievement on intelligence was higher in Russian language and history, but in algebra and geometry it was lower.

The Study 2 contribution was new and interesting data on the relationships between some SR processes and learning-activity outcomes: the higher the process of result evaluation, the higher Year Grades in all academic subjects of the study. As for other processes (planning, modeling, programming), they found correlations only with the subjects in which a lack of corresponding regulatory skill provides no success - for example, programming for Russian language, planning for literature, modeling for history.

As in Study 1, results obtained in Study 2 complement the studies investigating noncognitive and nonintellectual predictors of academic success. Thus, a number of studies found that regulation factors made a contribution that was more significant to higher academic outcomes than intelligence (Baumeister, Vohs, \& Tice, 2007; Duckworth \& Seligman, 2005; Duckworth, Peterson, Matthews, \& Kelly, 2007; Duckworth, Quinn, \& Tsukayama, 2012; Ishkov, 2004; Tangney, Baumeister, \& Boone, 2004).

The nature of the relationship between intelligence and SR remains a debatable issue. Nisbett pointed out at least three possible reasons, explaining the relationships between them: (1) the ability to consciously regulate one's own activity is probably a manifestation of intelligence; (2) both intelligence and SR may depend on a third factor; (3) conscious SR may turn out to be one of the factors fostering the development of intelligence (Nisbett et al., 2012). Scientists recognize the importance of developing SR skills and other noncognitive traits for high-level intellectual functioning (Blair, 2002; Calero, Garcia-Martin, Jimenez, Kazen, \& Araque, 2007; Diamond, Barnett, Thomas, \& Munro, 2007; Heckman, 2006). 
According to Konopkin (2011), intelligence, as one of the resources of SR, is of particular importance for its support. This conclusion makes a theoretical contribution to solving the problem of identifying the intellectual and regulatory predictors of academic success.

The regression models of academic success in the humanities identified the verbal intelligence associated with vocabulary as highly significant and definitive for success in these subjects.

Special attention should be paid to predictors of success in algebra and geometry, which mostly are based on the quantitative-relations test (Q2) and spatial intelligence. These facts also complemented the results in Study 1.

The obtained results allow us to state that sustained academic achievement even for intellectually gifted students is impossible without conscious SR of the learning activity. At the same time, teachers can facilitate awareness and development of the SR processes that contribute to academic success.

\section{Limitations and future research}

Despite its contributions, our research has some unavoidable limitations. Our study results do not give a clear answer to the question Is there a relationship between students' cognitive and regulatory characteristics? On the one hand, correlation analysis showed no linear relationship between them. On the other hand, a significant argument in favor of the existence of this relationship is the regression analysis data.

Intelligence makes a contribution that is more significant to academic success than that of SR. However, when it is included into a regression equation along with cognitive and regulation variances, this advantage becomes controversial.

For interpreting obtained data, note that the SRPLAQ questionnaire we used aims to identify SR stylistic features; therefore, it has significant limitations for analysis of the genesis of conscious SR in specific experimental situations.

The theoretical contribution of this study is based on the obtained evidence that conscious SR is a necessary competence for the realization of learning activity in general as well as for the manifestation and implementation of the mediator and facilitator of cognitive faculties. We assume that conscious SR, together with motivation, is an individual meta-competence that mobilizes cognitive and personal resources for the achievement learning goals. Verification of this assumption will be the basis for our future research.

\section{Conclusions}

First, conscious SR, along with intelligence and cognitive features, is a significant predictor of academic success that is consistently revealed in different samples while using different methods.

Second, the present study is the first to show the mediating role of SR in the relationship among intelligence, cognitive features, and academic success that is justified by the mediator analysis. 
Third, the relationship between cognitive and regulatory features is not direct but is distinctly revealed in their joint determination of different kinds of mathematical success. Conscious SR has a multitude of significant relationships with academic achievement, whereas cognitive features relate in a greater degree to success in solving mathematical problems for testing mathematical abilities.

Fourth, conscious SR and intelligence predict academic success regardless of whether the academic subject is the humanities, mathematics, or natural science. At the same time, this determination has its peculiarities in particular variables of intelligence and certain SR processes depending on the substantive characteristics of the academic subjects.

\section{Acknowledgments}

This study was supported by a grant from the Russian Foundation for Basic Research (project no. 13-06-00585A).

\section{References}

Averina, I. S., Shcheblanova, E. I., \& Perlet, K. (1991). Adaptatsiya myunkhenskikh testov poznavatel'nykh sposobnostei dlya odarennykh. uchashchikhsya [Adaptation Munich tests of cognitive abilities for gifted students]. Voprosy Psikhologii [Issues in psychology], 5, 173178.

Bartels, M., Rietveld, M. J., Van Baal, G. C., \& Boomsma, D. I. (2002). Heritability of educational achievement in 12-year-olds and the overlap with cognitive ability. Twin Research, 5(6), 544-553. doi: 10.1375/136905202762342017

Baumeister, R. F., Vohs, K. D., \& Tice, D. M. (2007). The strength model of self-control. Current Directions in Psychological Science, 16(6), 351-355. doi: 10.1111/j.1467-8721.2007.00534.x

Biryukov, S. D., \& Khodakova, E. Yu. (1999). Prediktory uspevaemosti v strukture flyuidnogo intellekta [Predictors of academic achievement in the structure of fluid intelligence]. In Intellekt $i$ tvorchestvo [Intelligence and Creativity] (pp. 66-78). Moscow: IP RAS.

Blair, C. (2002). School readiness: Integrating cognition and emotion in a neurobiological conceptualization of children's functioning at school entry. American Psychologist, 57, 111-127. doi: 10.1037/0003-066X.57.2.111

Boekaerts, M., Pintrich, P. R., \& Zeidner, M. (Eds.). (2005). Handbook of self-regulation. Amsterdam: Elsevier.

Bordovskaya, N. V., \& Rean, A. A. (2000). Pedagogika [Pedagogy]. St. Petersburg: Piter

Bouffard, T., Boisvert, J., Vezeau, C., \& Larouche, C. (1995). The impact of goal orientation on self-regulation and performance among college students. British Journal of Educational Psychology, 65, 317-329. doi: 10.1111/j.2044-8279.1995.tb01152.x

Brody, N. (2004). What cognitive intelligence is and what emotional intelligence is not. Psychological Inquiry, 234-238.

Calero, M. D., Garcia-Martin, M. B., Jimenez, M. I., Kazen, M., \& Araque, A. (2007). Self-regulation advantage for high-IQ children: Findings from a research study. Learning and Individual Differences, 17, 328-343. doi: 10.1016/j.lindif.2007.03.012

Cleary, T. J., \& Chen, P. P. (2009). Self-regulation, motivation, and math achievement in middle school: Variations across grade level and math context. Journal of School Psychology, 47(5), 291-314. doi: 10.1016/j.jsp.2009.04.002 
Corno, L. (2001). Volitional aspects of self-regulated learning. Self-regulated learning and academic achievement: Theoretical perspectives, 2, 191-225.

Deary, I. J., Der, G., \& Ford, G. (2001). Reaction times and intelligence differences: A populationbased cohort study. Intelligence, 29(5), 389-399. doi: 10.1016/S0160-2896(01)00062-9

Diamond, A., Barnett, W. S., Thomas, J., \& Munro, S. (2007). Preschool program improves cognitive control. Science, 318(5855), 1387. doi: 10.1126/science.1151148

Dirik, A., Bogdanova, O. E., \& Kovas, Y. V. (2012). Issledovanie vzaimosvyazi akademicheskikh dostizhenii s sotsial'no-ekonomicheskim statusom, kognitivnymi sposobnostyami, i samootsenkoi matematicheskikh sposobnostei uchashchikhsya starshikh klassov [An investigation of the interrelationship between academic achievement, socioeconomic status, cognitive abilities, and self-perceived mathematical abilities in high school students]. Teoreticheskaya $i$ Eksperimental'naya Psikhologiya [Theoretical and experimental psychology], 5(4), 5-19.

Diseth, Å., \& Kobbeltvedt, T. (2010). A mediation analysis of achievement motives, goals, learning strategies, and academic achievement. British Journal of Educational Psychology, 80(4), 671-687. doi: 10.1348/000709910X492432

Druzhinin, V. N. (2001). Kognitivnye sposobnosti: Struktura, diagnostika, razvitie [Cognitive abilities: Structure, diagnostics, development]. Moscow: PerSe, St. Petersburg: Imaton-M.

Duckworth, A. L., Peterson, C., Matthews, M. D., \& Kelly, D. R. (2007). Grit: Perseverance and passion for long-term goals. Personality Processes and Individual Differences, 92(6), 10871101. doi: 10.1037/0022-3514.92.6.1087

Duckworth, A. L., Quinn, P. D., \& Tsukayama, E. (2012). What No Child Left Behind leaves behind: The roles of IQ and self-control in predicting standardized achievement test scores and report card grades. Journal of Educational Psychology, 104(2), 439. doi: 10.1037/a0026280

Duckworth, A. L., \& Seligman, M. E. (2005). Self-discipline outdoes IQ in predicting academic performance of adolescents. Psychological Science, 16, 939-944. doi: 10.1111/j.1467-9280 .2005.01641.x

Elliot, A. J., McGregor, H. A., \& Gable, S. (1999). Achievement goals, study strategies, and exam performance: A mediational analysis. Journal of Educational Psychology, 91(3), 549-563. doi: 10.1037/0022-0663.91.3.549

Geary, D. C. (2011). Cognitive predictors of achievement growth in mathematics: A 5-year longitudinal study. Developmental Psychology, 47(6), 1539. doi: 10.1037/a0025510

Ginsburg, H. P., \& Baroody, A. J. (1990). Test of early mathematics ability: Examiner's manual. Austin, TX: Pro-Ed.

Golubeva, E. A., Izyumova, S. A., \& Kabardov, M. K. (1991). Opyt kompleksnogo issledovaniya uchashchikhsya $v$ svyazi s nekotorymi problemami differentsiatsii obucheniya [The experience of a comprehensive investigation of students in connection with some problems of differentiation in teaching]. Voprosy Psikhologii [Issues in psychology], 2, 132-140.

Gordeeva, T. O. (2013). Motivatsiya uchebnoi deyatel'nosti shkol'nikov i studentov: Struktura, mekhanizmy, usloviyarazvitiya [Motivation of the educational activity of pupils and students: structure, mechanisms, conditions] (Unpublished doctoral dissertation). Moscow: Lomonosov Moscow State University.

Gordeeva, T. O., Leontiev, D. A., \& Osin, E. N. (2011). Vklad lichnostnogo potentsiala v akademicheskie dostizheniya [The contribution of personal potential to academic achievement]. In D. A. Leontiev (Ed.), Personal potential: Structure and diagnostics (pp. 642-667). Moscow: Smysl.

Gordeeva, T. O., \& Osin, E. N. (2012). Osobennosti motivatsii dostizheniya i uchebnoi motivatsii studentov, demonstriruyushchikh raznye tipy akademicheskikh dostizhenii (EGE, pobedy $v$ olimpiadakh, akademicheskaya uspevaemost') [Differences in achievement motivation and 
learning motivation in students exhibiting different types of academic attainment (Unified State Examination (USE) scores, academic competition results, academic records)]. Psikhologicheskie Issledovaniya [Psychological research], 5(24), 4. Retrieved from http:// psystudy.ru

Gottfredson, L. S. (2004). Schools and the g factor. Wilson Quarterly, Summer, 35-45.

Greven, C. U., Harlaar, N., Kovas, Y., Chamorro-Premuzic, T., \& Plomin, R. (2009). More than just IQ: School achievement is predicted by self-perceived abilities - but for genetic rather than environmental reasons. Psychological Science, 20(6), 753-762. doi: 10.1111/j.14679280.2009.02366.x

Hackett, G., \& Betz, N. E. (1989). An exploration of the mathematics self-efficacy/mathematics performance correspondence. Journal for Research in Mathematics Education, 20, 261-273. doi: $10.2307 / 749515$

Halberda, J., Mazzocco, M. M., \& Feigenson, L. (2008). Individual differences in non-verbal number acuity correlated with maths achievement. Nature, 455(7213), 665-668. doi: 10.1038 /nature07246

Heckman, J. J. (2006). Skill formation and the economics of investing in disadvantaged children. Science, 312, 1900-1902. doi: 10.1126/science.1128898

Ishkov, A. D. (2004). Uchebnaya deyatel'nost' studenta: Psikhologicheskie faktory uspeshnosti [Learning activity of students: Psychological factors of success] (Unpublished doctoral dissertation). Moscow: Lomonosov Moscow State University.

Ivannikov, V.A. (2006). Psikhologicheskie mekhanizmy volevoi regulyatsii [Psychological mechanisms of volition regulation]. Saint Petersburg: Piter.

Karpov, A. V. (2011). Teoreticheskie i eksperimental'nye osnovy issledovaniya metakognitivnoi regulyatsii deyatel'nosti [Theoretical and experimental bases of the research on the regulation of metacognitive activity]. In E. I. Morosanov, (Eds.), Psychology of self-regulation in the XXI century (pp. 90-125). St. Petersburg, Moscow: Nestor-Istoriya.

Kochergina, E. V., Nye, J., \& Orel, E. A. (2013). Faktory «Bol'shoi pyaterki» kak psikhologicheskie prediktory akademicheskoi uspevaemosti studentov vuzov [The Big Five traits as psychological predictors of academic achievement in university students]. Psikhologicheskie Issledovaniya [Psychological research], 6(27), 4. Retrieved from http://psystudy.ru

Konopkin, O. A. (2011). Psikhologicheskie mekhanizmy regulyatsii deyatel'nosti [Psychological mechanisms of the regulation of activity]. Moscow: LENAND.

Konopkin, O. A., \& Prygin, G. S. (1984). Svyaz' uchebnoi uspevaemosti studentov s individual'notipologicheskimi osobennostyamiikh samoregulyatsii [Correlation between students' learning activity and their individual-typological peculiarities of self-regulation]. Voprosy Psikhologii [Issues in psychology], 3, 42-52.

Kornilov, S. A. (2012). Kross-kul'turnaya invariantnost' analiticheskikh, tvorcheskikh, i prakticheskikh sposobnostei rossiiskikh, angliiskikh, i amerikanskikh uchashchikhsya [Crosscultural invariance of analytical, creative, and practical abilities of Russian, British, and American students] (Unpublished doctoral dissertation). Moscow: Lomonosov Moscow State University.

Kornilov, S. A., Grigorenko, E. L., \& Smirnov, S. D. (2009). Longityudnoe issledovanie akademicheskikh, tvorcheskikh, i prakticheskikh sposobnostei kak predposyloku speshnosti obucheniya [A longitudinal study of academic, creative, and practical abilities as preconditions of success in learning]. Voprosy Psikhologii [Issues in psychology], 5, 138-149.

Kornilova, T.V. (2008). Personality regulation of decision making and learning efficacy. Psychology in Russia: State of Art, 1, 162-181. doi: 10.11621/pir.2008.0011

Kornilova, T. V., Kornilov, S. A., \& Chumakova, M. A. (2009). Subjective evaluations of intelligence and academic self-concept predict academic achievement: Evidence from a selec- 
tive student population. Learning and Individual Differences, 19(4), 596-608. doi: 10.1016/j. lindif.2009.08.001

Kornilova, T. V., \& Novikova, M. A. (2013). Self-assessed intelligence, psychometric intelligence, personality, and academic achievement: Two structural models. In Educational achievement: Teaching strategies, psychological factors and economic impact (pp. 197-212). New York: Nova Science.

Krapohl, E., Rimfeld, K., Nicholas, G., Shakeshaft, N., Trzaskowski, M., McMillan, A., \& Plomin, R. (2014). The high heritability of educational achievement reflects many genetically influenced traits, not just intelligence. Proceedings of the National Academy of Sciences, USA, 111, 15273-15278. doi: 10.1073/pnas.1408777111

Kruglova, N. F. (2000). Ekspress-diagnostika i korrektsiya regulyatorno-kognitivnoi struktury uchebnoi deyatel'nosti podrostkov [Express diagnostics and the correction of the regulatory and cognitive structure of the learning activity of students]. Moscow: PI RAE, Ekopsitsentr ROSS.

Leontyev D. A., \& Averina, A. J. (2011). Fenomen refleksii v kontekste problemy samoregulyacii [The phenomenon of self-reflection in the context of self-regulation problem]. Psihologicheskie issledovaniya [Psychological research], 2(16). Retrieved from: http://psystudy.ru

Luo, Y. L., Kovas, Y., Haworth, C. M., \& Plomin, R. (2011). The etiology of mathematical selfevaluation and mathematics achievement: Understanding the relationship using a crosslagged twin study from ages 9 to 12. Learning and Individual Differences, 21(6), 710-718. doi: 10.1016/j.lindif.2011.09.001

McCaslin, M., \& Hickey, D. T. (2001). Self-regulated learning and academic achievement: A Vygotskian view. Self-regulated Learning and Academic Achievement: Theoretical Perspectives, 2, 227-252.

Morosanova, V. I. (2010). Conscious self-regulation of voluntary activity: Differential approach. Psychology in Russia: State of the Art, 3, 333-349. doi: 10.11621/pir.2010.0017

Morosanova, V. I. (2011). Razvitie teorii o soznannoi samoregulyatsii: Differentsial'nyi podkhod [Development of a theory of conscious self-regulation: A differential approach]. Voprosy Psychologii [Issues in psychology], 3, 132-144.

Morosanova, V. I. (2013a). Differentsial'no-psikhologicheskie osnovy samoregulyatsii v obuchenii i vospitanii podrastayushchego pokoleniya [Differential and psychological bases of self-regulation in the education and upbringing of the younger generation]. Mir Psikhologii [World of psychology], 2, 189-200.

Morosanova, V. I. (2013b). Self-regulation and personality. Procedia - Social and Behavioral Sciences, 86, 452-457.

Morosanova, V. I. (2014). Osoznannaya samoregulyatsiya cheloveka kak psikhologicheskii resurs dostizheniya uchebnykh i professional'nykh tselei [Conscious personal self-regulation as a psychological resource for achieving educational and professional goals]. Teoreticheskaya $i$ Eksperimental'naya Psikhologiya [Theoretical and experimental psychology], 4, 16-38.

Morosanova, V. I., \& Filippova, E. V. (2009). Izuchenie regulyatornykh osnov psikhologicheskoi uspeshnosti uchashchikhsya na ekzamene [A study of the regulatory bases of the psychological success of students in an exam situation]. Vestnik Rossiiskogo Universiteta Druzhby Narodov. Seriya: Psikhologiya i Pedagogika [Bulletin of the Peoples' Friendship University of Russia. Series: Psychology and pedagogy], 4, 37-43.

Morosanova, V. I., Filippova, E. V., \& Fomina, T. G. (2014). Lichnostnye i regulyatornye prediktory uspeshnosti i nadezhnosti deistvii shkol'nikov v situatsii ekzamena. [Personal and regulatory predictors of the academic success and reliability of the actions of students in an exam situation]. Vestnik Moskovskogo Universiteta. Seriya 14. Psikhologiya [Moscow University Psychology Bulletin], 4, 4-17. 
Morosanova, V. I., Fomina, T. G., \& Kovas, Yu. V. (2014). Vzaimosvyaz' regulyatornykh, intellektual'nykh, i kognitivnykh osobennostei uchashchikhsya $s$ matematicheskoi uspeshnost'yu [The relationship among the regulatory, intellectual, and cognitive characteristics of students who are successful in mathematics]. Psikhologicheskie Issledovaniya [Psychological research], 7(34), 11. Retrieved from http://psystudy.ru

Morosanova, V. I., Shcheblanova, E. I., Bondarenko, I. N., \& Sidikov, V.A. (2013). Vzaimosvyaz' psikhometricheskogo intellekta, osoznannoi samoregulyatsii uchebnoi deyatel'nosti i akademicheskoi uspevaemostiodarennykh podrostkov [The relationship among the psychometric intelligence, conscious self-regulation of learning activity, and academic achievement of gifted adolescents]. Vestnik Moskovskogo Universiteta. Seriya 14. Psikhologiya [Moscow University Psychology Bulletin], 3, 18-32.

Morosanova, V. I., Vanin, A. V., \& Tsyganov, I. Yu. (2011). Sozdanie novoi versii oprosnogo metoda "Stil' samoregulyatsii uchebnoi deyatel'nosti - SSUDM" [Creating a new version of the questionnaire method "Self-Regulation Profile of Learning Activity Questionnaire SRPLAQ"]. Teoreticheskaya i Eksperimental'naya Psikhologiya [Theoretical and experimental psychology], 4(1), 5-15.

Murphy, M. M., \& Mazzocco, M. M. (2008). Mathematics learning disabilities in girls with fragile X or Turner syndrome during late elementary school. Journal of Learning Disabilities, 41(1), 29-46. doi: 10.1177/0022219407311038

Nisbett, R. E., Aronson, J., Blair, C., Dickens, W., Flynn, J., Halpern, D.F., \& Turkheimer, E. (2012). Intelligence. American Psychologist, 67(2), 130-159. doi: 10.1037/a0026699

Opfer, J. E., \& Siegler, R. S. (2007). Representational change and children's numerical estimation. Cognitive Psychology, 55(3), 169-195. doi: 10.1016/j.cogpsych.2006.09.002

Pagulayan, K., Busch, R. M., Medina, K. L., Bartok, J. A., \& Krikorian, R. (2006). Developmental normative data for the Corsi block-tapping task. Journal of Clinical and Experimental Neuropsychology, 28(6), 1043-1052. doi: 10.1080/13803390500350977

Pintrich, P. R., \& De Groot, E. V. (1990). Motivational and self-regulated learning components of classroom academic performance. Journal of Educational Psychology, 82(1), 33. doi: 10.1037/0022-0663.82.1.33

Poropat, A. E. (2009). A meta-analysis of the five-factor model of personality and academic performance. Psychological Bulletin, 135(2), 322. doi: 10.1037/a0014996

Reis, S. M., \& McCoach, D. B. (2002). Underachievement in gifted students. In M. Neihart, S. M. Reis, N. M. Robinson, \& S. M. Moon (Eds.), The social and emotional development of gifted children. What do we know? (pp. 81-91). Waco, TX: Profrock Press.

Richardson, M., Abraham, C., \& Bond R. (2012). Psychological correlates of university students' academic performance: A systematic review and meta-analysis. Psychological Bulletin, 138(2), 353-387. doi: 10.1037/a0026838

Rodic, M., Tikhomirova, T., Kolienko, T., Malykh, S., Bogdanova, O., Zueva, D. Y., \& Kovas, Y. (2015). Spatial complexity of character-based writing systems and arithmetic in primary school: A longitudinal study. Frontiers in Psychology, 6. Retrieved from: http://journal.frontiersin.org/article/10.3389/fpsyg.2015.00333/full doi: 10.3389/fpsyg.2015.00333

Raven, J. C., Court, J. H., \& Raven, J. (1996). Manual for Raven's standard progressive matrices. Oxford, England: Oxford Psychologists Press.

Rohde, T. E., \& Thompson, L. A. (2007). Predicting academic achievement with cognitive ability. Intelligence, 35(1), 83-92. doi: 10.1016/j.intell.2006.05.004

Ross, Y., Budakova, A.V., Malykh, A. S., \& Vorobyev, V. S. (2012). Chuvstvo chisla i matematicheskaya uspeshnost' u 16-17-letnikh yunoshei [Number sense and mathematical achievement in 16-17-year-old male students]. Teoreticheskaya i Eksperimental'naya Psikhologiya [Theoretical and experimental psychology], 5(4), 40-48. 
Schunk, D. H. (1990). Goal setting and self-efficacy during self-regulated learning. Educational Psychologist, 25(1), 71-86. doi: 10.1207/s15326985ep2501_6

Sergienko E. A. (2008). Subyektnaya regulyatsiya sovladayushchego povedeniya [Subjective regulation of coping behavior]. In A.L. Zhuravlev, T. L. Kryukova, \& E.A. Sergienko (Eds.), Sovladayushchee povedenie: Sovremennoe sostoyanie i perspektivy [Coping: Current status and prospects]. (pp. 67-83). Moscow: IP RAS.

Shcheblanova, E. I. (1999). Osobennosti kognitivnogo i motivatsionno-lichnostnogo razvitiya odarennykh starshe klassnikov [Features of the cognitive and motivational-personality development of gifted high school students]. Voprosy Psikhologii [Issues in psychology], 6, $36-47$.

Shcheblanova, E. I. (2004). Psikhologicheskaya diagnostika odarennosti shkolnikov: Problemy, metody, rezul'taty issledovanii i praktiki [Psychological diagnosis of gifted students: Problems, methods, results of research, and practice]. Moscow: Publishing House of the Moscow Psychological and Social Institute.

Shcheblanova, E. I. (2013). Vzaimosvyaz' kognitivnykh sposobnostei i lichnostnykh kharakteristik intellektual'no odarennykh shkol'nikov [The relationship of the cognitive abilities and personal characteristics of intellectually gifted students]. Voprosy Psikhologii [Issues in Psychology], 1, 13-23.

Shepard, R. N., \& Metzler, J. (1971). Mental rotation of three-dimensional objects. Science, 171, 701-703. doi: 10.1126/science.171.3972.701

Shumakova, N. B. (2006). Razvitie obshchei odarennosti detei v usloviyakh shkol'nogo obucheniya [Development of the general endowments of children in school]. (Unpublished doctoral dissertation). Moscow: Psychological Institute of Russian Academy of Education.

Siegler, R. S., \& Opfer, J. E. (2003).The development of numerical estimation evidence for multiple representations of numerical quantity. Psychological Science, 14(3), 237-250. doi: $10.1111 / 1467-9280.02438$

Smirnov, S. D., Kornilova, T. V., Kornilov, S. A., \& Malakhova, S. I. (2007). O svyazi intellektual'nykh i lichnostnykh kharakteristik studentov s uspeshnost'yuikh obucheniya [About the connections between intellectual abilities and personality traits of students and their training success]. Vestnik Moskovskogo Universiteta. Seriya 14. Psikhologiya [Moscow University Psychology Bulletin], 3, 82-87.

Spinath, B., Spinath, F. M., Harlaar, N., \& Plomin, R. (2006). Predicting school achievement from general cognitive ability, self-perceived ability, and intrinsic value. Intelligence, 34(4), 363-374. doi: 10.1016/j.intell.2005.11.004

Steinmayr, R., \& Spinath, B. (2009).The importance of motivation as a predictor of school achievement. Learning and Individual Differences, 19(1), 80-90. doi: 10.1016/j.lindif.2008.05.004

Sternberg, R. J., Grigorenko, E., \& Bundy, D. A. (2001). The predictive value of IQ. MerrillPalmer Quarterly, 47(1), 1-41. doi: 10.1353/mpq.2001.0005

Tangney, J. P., Baumeister, R. F., \& Boone, A. L. (2004). High self-control predicts good adjustment, less pathology, better grades, and interpersonal success. Journal of Personality, 72(2), 271-322. doi: 10.1111/j.0022-3506.2004.00263.x

Tikhomirova, T. N., \& Kovas, Y. V. (2012). Rol' kognitivnykh pokazateley uchashchikhsya starshego shkol'nogo vozrasta $\mathrm{v}$ uspeshnosti resheniya matematicheskikh zadaniy [The role of the cognitive characteristics of Russian high school students in the successful resolution of mathematical problems]. Znanie. Ponimanie. Umenie [Knowledge. Understanding. Ability], 2, 237-244.

Tikhomirova, T.,N., \& Kovas, Y. V. (2013). Vzaimosvyaz' kognitivnykh kharakteristik uchashchikhsya i uspeshnosti resheniya matematicheskikh zadanii (naprimere starshego shkol'nogo vozrasta) [Interrelationship of the cognitive characteristics of students and the successful 
resolution of mathematical problems (through the example of high school pupils)]. Psikhologicheskii Zhurnal [Psychological journal], 34(1), 63-73.

Winne, P. H. (1995). Self-regulation is ubiquitous but its forms vary with knowledge. Educational Psychologist, 30(4), 223-228. doi: 10.1207/s15326985ep3004_9

Zimmerman, B. J., Bandura, A., \& Martinez-Pons, M. (1992). Self-motivation for academic attainment: The role of self-efficacy beliefs and personal goal setting. American Educational Research Journal, 29(3), 663-676. doi: 10.3102/00028312029003663

Zimmerman, B. J., \& Schunk, D. H. (1989). Self-regulated learning and academic achievement: Theory, research, and practice. Berlin: Springer. doi: 10.1007/978-1-4612-3618-4

Original manuscript received June 03, 2015 Revised manuscript accepted July 30, 2015

First published online September 30, 2015 